Resenhas | Book Reviews

\title{
MONTEIRO, Marko Synésio Alves. Os dilemas do humano: reinventando o corpo numa era (bio)tecnológica. São Paulo: Anablume, 2012. 168 p.
}

Gil Vicente Nagai Lourenção*

*Universidade Estadual de Campinas - Campinas, SP, Brasil

Em pós-doutoramento (bolsista Fapesp)

gilvicenteworks@gmail.com

https://orcid.org/0000-0002-9685-1226 
Este livro se debruça sobre o tema geral dos estudos sociais da ciência e tecnologia (ESCT), e se constitui como um trabalho relevante para pesquisadores e interessados em desenvolver pesquisas nos ESCT. Meu interesse nessa leitura deriva de minhas pesquisas em torno da DIYBio, ou seja, das práticas científicas em termos da relação humano-máquina e das manipulações corporais presentes nas biotécnicas da Do It Yourself Biology. Dessa forma, penso que o livro de Monteiro, embora de publicação em 2012, é uma obra inescapável para se pensar as diversas relações biotecnocientíficas.

A apresentação é feita pelo professor Laymert Garcia dos Santos, que nos conduz ao modo problemático através do qual o homem ocidental expressa sua relação com o próprio corpo. Por sua vez o autor explora os dilemas do ser humano diante de um corpo humano cujo estatuto passa por uma transformação radical - que marca uma reinvenção. Seu ponto de partida é o modo como a biologia molecular e as biotecnologias investem o corpo e o pré-configuram; seu ponto de chegada é o modo como a arte contemporânea, sobretudo as artes plásticas, respondem a essa reconfiguração. O dilema então passa a ser, ao final, aceitar a individuação programada ou insurgir-se.

O objetivo do livro é debater as novas relações entre ciência, tecnologia e corporalidade numa discussão sobre as maleabilidades da materialidade e representação. A pesquisa de campo foi desenvolvida ao longo de alguns meses em laboratórios de bioinformática na cidade de São Paulo. No desenvolvimento do trabalho a figura exemplar que aparece é a do ciborgue de Haraway (2000, 2016; Haraway; Goodeve, 2015), e a interpretação original que o autor confere a esse conceito é notável. Tanto o estudo empreendido no livro quanto o campo de pesquisa mais geral onde ele se insere se ocupam na compreensão de como o conhecimento gerado em laboratórios é construído na prática; e igualmente tal conhecimento se relaciona com o espaço e com o tempo no qual foi construído, tornando-se assim um elemento de composição desse mesmo espaço, tempo e tecido sociais.

No primeiro capítulo, Monteiro apresenta um estudo de caso sobre biomarcadores de câncer de próstata com o objetivo de oferecer uma visão dos novos relacionamentos entre a matéria viva e as tecnologias discutidas no livro. O objeto desse debate é o chip de DNA - microarray - onde se estabelecem as extensões de DNA para determinar como elas reagem aos medicamentos. Nesse chip está contida a matéria orgânica em uma lâmina, que será 
o elemento da análise laboratorial, e a partir da ciência e práticas de sua manipulação foi possível de se fazer no livro uma discussão sobre a percepção do corpo como objeto de informação manipulável. Tal artefato funciona como um ciborgue em miniatura, e segue uma lógica de representação e manipulação lógica enquanto uma parte de um corpo digital. $\mathrm{O}$ autor buscou aqui distinguir a ideia do "corpo como máquina" da ideia do "corpo como informação" que foi se desenvolvendo nos laboratórios. Por meio do estudo dos biomarcadores o autor pouco a pouco nos diz que tal objeto é importante porque ele incorpora as novas tecnologias de acesso ao corpo, na medida em que o corpo se torna um objeto informacional. Apesar das dificuldades de permeabilidade do campo, a linha de coerência da pesquisa se deu pela busca das concepções de corpo dos profissionais que trabalhavam com esses biomarcadores. $\mathrm{O}$ autor descobriu que a dicotomia corpo/mente é muito presente junto ao coletivo em análise, apesar de a pesquisa com o chip delinear uma nova visão do corpo que, conforme nota, não é consciente e/ou articulável no imaginário científico coberto pela pesquisa.

O capítulo dois discute problemas teóricos envolvendo a sociologia da ciência e suas consequências epistemológicas. Apresentando o debate existente entre autores pioneiros no campo de estudos sociais da ciência e tecnologia (como Pickering, Kuhn, Bourdieu, Merton, Latour, Woolgar), Monteiro discute a ideia da "ciência como prática" para apresentar a ciência enquanto um conhecimento socialmente construído, ou seja, enquanto uma "prática social". Nesse sentido, as outras ciências que não são os ESCT entendem a ciência como atividade, como prática; já os estudos da ciência veem a necessidade de argumentar e igualmente investigar quais são de fato as condições de possibilidade enquanto práticas sociais. Por sua vez, a compreensão da mudança conceitual implícita nos estudos sociais de práticas cientificas abre espaço para a compreensão de como essas práticas antecipam o futuro (p. 55).

No capítulo três, o autor apresenta o corpo como objeto da teoria social de um ponto de vista cartesiano, que vê a mente separada do corpo (reduzindo o último à sua materialidade). Ele então mostra como essa visão do corpo é insuficiente para explicar os novos desenvolvimentos associados à tecnologia. Referindo-se a Turner, Pierre Bourdieu, Csordas, Merleau-Ponty, Michel Foucault e diversos estudos feministas citados ao longo do capitulo, o autor discute a relação entre natureza e cultura, e a reflexividade do corpo na cultura de 
consumo. A partir dessa discussão o autor conclui que as tecnologias ligadas à análise genética devem ser entendidas para além de uma noção "representacional". Monteiro chama a atenção para a ideia de controle como uma prática científica, e sobre as formas em que ele começa a se desenvolver historicamente enquanto uma esfera biomédica. Ainda destaca a centralidade de uma leitura feminista como uma abordagem inovadora para pensar o corpo na relação entre ciência e tecnologia.

O quarto capítulo trabalha os conceitos de humano e humanismo, tomando como ponto de partida um novo padrão de representação artística do homem que ocorre no Renascimento europeu. Monteiro demonstra como se deu a chamada ruptura cartesiana e o advento do corpo-máquina. $\mathrm{O}$ corpo é ordenado e torna-se matéria funcional e analítica. Nessa leitura, o surgimento de um contexto intelectual propício é importante e marca o aparecimento de uma ideia de conhecimento não subordinado à esfera celeste, mas (in)constantemente humano. Caberia ao homem a decifração da natureza, e seu enquadramento matemático, prática feita por diversos sujeitos históricos no Renascimento e Pós-Renascimento europeu. Apesar de o corpo ser algo que se aproxima da natureza, ele é ao mesmo tempo algo que se afasta, que possui seu próprio regime de funcionamento; uma máquina com uma forma própria de funcionamento, o que levará à discussão presente no empirismo, no organicismo e na mecânica.

A teoria genética como o novo dogma da biologia é o objeto do quinto capítulo. Para o autor, os pressupostos da biologia molecular são diretamente relacionados às explicações mecanicistas. A genética passa a ser considerada enquanto detentora da verdade sobre a vida e o gene se torna uma entidade material usada para explicar isso, conforme o advento dos modelos matemáticos de Watson e Crick. Nesse caso, a biologia molecular e a teoria genética fornecem uma explicação para a vida em uma visão materialista e reducionista. $\mathrm{O}$ autor demonstra como a biologia molecular aparece enquanto um discurso de verdade, ao postular que o DNA e o RNA teriam a partir daquele momento uma configuração funcional, de armazenar e transmitir informação. Logo, a materialidade do corpo muda de qualidade. Mudança capital, quando passa a ser a informação que define os contornos da vida.

No capítulo seis, ele apresenta uma discussão das possíveis consequências desses processos, e passa a discutir questões políticas que são levantadas pela 
possibilidade de manipular o corpo no capitalismo tecnocientífico. O potencial aqui é interpretado como uma maneira possível de vincular tecnologia, corpo e política a partir da experiência biotecnológica, algo cuja atualidade é notável. Essa questão torna-se central, como um exemplo histórico da expressão mais radical de uma lógica de biopolitização da vida, quando são seguidas as demandas crescentes da indústria. Por exemplo, aquilo que chamamos de natureza; usando uma análise de Laymert Garcia dos Santos $(2000,2003)$ ele exemplifica como a natureza é vista por ambos os lados do conflito como "capital". O embate ocorre não entre campos opostos, mas entre vertentes diversas de um mesmo ímpeto de apropriação da natureza pela tecnociência (p. 106). Destaca-se a discussão a respeito das práticas eugênicas, e o nexo entre saber e poder que a elas deu sustentação continua intacto, e crescentemente reforçado pelo saber biotecnológico atual (p. 111-120).

Em contraste com o capítulo seis, o capítulo sete examina as práticas de recriação do corpo de uma forma distinta daquelas oferecidas pelas práticas eugênicas. $\mathrm{O}$ foco está na manipulação da matéria viva para novos fins ético-estéticos. Nesse sentido a bioarte aparece aqui como uma mobilização particular do potencial presente nos avanços da genética, uma vez que ela desloca a prática dos laboratórios para promover um debate ético sobre a relação entre a tecnologia e a vida. Isso permite antecipar virtualidades, enquanto potenciais não efetivados, e criar novos usos éticos da tecnologia; dessa forma tanto a ética quanto a estética tornam-se armas críticas contra a possibilidade de um determinismo genético, biotecnológico e eugênico, ou seja, a arte como uma reinvenção do corpo, enquanto uma antecipação de novos devires para o humano a partir de sua relação com a tecnologia.

Em sua conclusão, Monteiro salienta que a biotecnologia precisa ser repensada, e que o potencial eugênico inerente ao seu funcionamento deve ser problematizado. $\mathrm{O}$ autor sugere que devemos buscar novos e diferentes usos e interpretações para as biotecnologias, mais consistentes com nossos ideais democráticos, e que isso possivelmente as habilitariam a preservar as formas de vida existentes. Ao pensar a respeito da possibilidade de reinvenção do corpo em uma era biotecnológica, muitas e múltiplas questões aparecem e o livro de Marko Monteiro apresenta uma extensa lista e finas análises. Este livro, em suma, é de uma leitura intensa, altamente relevante para estudiosos interessados em investigar esse corpo humano, demasiado humano em suas 
relações com (novas) (bio)tecnologias, mas não só. Penso que este livro é muito útil nos dias sombrios que seguem, dias esses cuja promiscuidade do estado de exceção com um viés autoritário causa preocupação a todos aqueles que tentam realizar alguma ciência neste país.

\section{Referências}

HARAWAY, D. Manifesto ciborgue: ciência, tecnologia e feminismo-socialista no final do século XX. In: SILVA, T. T. da. (org.). Antropologia do ciborgue: as vertigens do pós-humano. Belo Horizonte: Autêntica, 2000. p. 39-129.

HARAWAY, D. Staying with the trouble: making kin in the Chthulucene. Durham: Duke University Press, 2016.

HARAWAY, D.; GOODEVE, T. Fragmentos: quanto como uma folha. Entrevista com Donna Haraway. Mediações, v. 20, n. 1, p. 48-68, 2015.

SANTOS, L. G. dos. Código primitivo-código genético: a con-sistência de uma vizinhança. In: ALLIEZ, E. (org.). Gilles Deleuze: uma vida filosófica. São Paulo: Editora 34,2000 . p. 415-421.

SANTOS, L. G. dos. Politizar as novas tecnologias: o impacto sócio-técnico da informação digital e genética. São Paulo: Editora 34, 2003. 